\title{
THE ISSUE OF THE TERM «SECT» JURIDICAL DEFINITION
}

\author{
Anatolij K. Pogasij ${ }^{1}$ \\ Elena V. Kuzmina ${ }^{2}$
}

\begin{abstract}
This article is devoted to the problem of the concept "sect" determination in religious studies and legal discourses. The paper presents the analysis of the etymology and use of the term "sect" in the history of philosophical, theological and religious thought. The authors advocate the position that there is no clear and consistent definition of the concept "sect" in modern religious science. The authors also express doubts about the possibility of an unambiguous definition of this concept development. The article expresses concern that an attempt to give and legislate a legal definition of the concept of "sect" (including "totalitarian sect" and "destructive cult") may lead to the practice of unfair enforcement and other negative consequences in the context of Russian reality.
\end{abstract}

Keywords: sect, totalitarian sect, destructive cult, sect studies, legal religious studies.

\section{Introduction}

On July 30, 2018, the Office of the State Duma of the Russian Federation posted a notice on the State procurement website about an open tender for the provision of expert analysis on the following topic: "Legislative regulation improvement for citizen right protection from illegal actions of sects and extremist religious organizations" [1]. The terms of reference include: "The assessment of the appropriateness of "sect", and "destructive cult" concept incorporation into the legislation [2].

The next day, July 31 , the chairman of the commission for public associations and religious organizations of the Moscow City Duma A. Paleev said that he had prepared a proposal to the State Duma on the possibility of considering the introduction of the concept of "sect" in the legislation. According to him, "in our modern world, a sect is not only a religious organization,

\footnotetext{
${ }^{1}$ Kazan Federal University, Kazan, Russia. bossloko1@yandex.ru, +79179201337.

${ }^{2}$ Kazan Federal University, Kazan, Russia. bossloko1@yandex.ru, +79179201337.
} 
as was thought at the beginning and middle of the twentieth century. Many famous philosophers defined sects, but everything is already outdated, because now modern science has such universal tools that help to get to human consciousness. (...) Sects should include not only religious organizations, but also supposedly scientific, educational and commercial organizations" [3].

At the highest level, they talked about the "sect problem" several years ago. The senator Elena Mizulina stated the need to draft a bill aimed at "destructive public associations and religious sect" prevention, as well as to record the term "destructive sect" legislatively (2016) [4]. For this purpose, a working group (32 people) was created, consisting of officials of various levels and departments, lawyers, security officials, doctors, one religious scholar, several so-called "sectologists", including the "main sectologist" A. Dvorkin (this is a self-name, because The "sect" has not yet been defined, but there are already sectologists!), the representatives of faiths (again, out of at least thirty faiths operating in Russia, only Orthodox Christians were included in the working group).
A closer look at the composition of the group gives the feeling of a certain predetermination of its work results: in March 2017, journalists asked one of the members of the group, A. E. Vayts, what criteria will the group be guided by during legislation development in the field of religion? The latter answered: "Everything that destroys a person must be destroyed!". And when he was asked who will determine how and what destroys a man, he explained: "These are passions: the lust of flesh, the lust of eyes and the pride of life. And the one who condones this is the one who destroys!" Restless journalists asked how these criteria (lust, etc.) will be revealed. Weitz assured that the "customer" of the future bill "is capable of feeling spiritual danger from the sects" [5]. It seems that with such "scientific" criteria, one can speak not about prejudice, but rather about doom ... Especially when you find out that the project budget is 4 million rubles, i.e. the order will be exactly executed, because you need to report for the money.

At first glance it seems that there is nothing strange here. There is a demand, there is a proposal, there is a contractor who will fulfill the order and 
receive his money without much difficulty.

In fact, the problem is much more complicated. Only a list of literature, which to one degree or another touches on the issues related to the origin, use, criticism of the term "sect", not to mention the sources where this word is used in various meanings, will take more than a dozen pages. The "sect" in various variations is used so widely and uncontrollably that, apparently, it becomes a threat to the stability of interconfessional and interethnic relations.

Despite the absence of this term in the legislation, it penetrated both the judicial practice ${ }^{1}$ and the vocabulary of public servants, who often use it to identify any confessions not traditional for Russia.

The purpose of this article is to draw the reader's attention to another attempt by the Russian authorities to give a legal definition of the word "sect" (and even more so - "totalitarian sect" and "destructive cult") and to predict the consequences of this dubious initiative in the context of Russian reality.

\section{Methods}

Taking into account the task we set to analyze the multiple approaches to the definition of the concept "sect," the article used such general scientific methods as the method of historical and logical unity in cognition, a systematic approach, as well as general logical research methods: analysis, synthesis, comparison and generalization.

\section{Results and Discussion}

Even in antiquity, the term "sect" was used in several meanings:

- lifestyle, mode of action, way of thinking [6, p. 242];

- school, path, teaching, trend [7, p. 969];

- a group separated from any major current (including religious), professing a new idea or following a new leader [8, p. 316];

- a political group [9, p. 523];

- and even a robber gang [10, p. 108].

The etymology of the word is also ambiguous. Some believe that it came from the Latin secta, the derivative from sequor - "follow someone" [11, p. 1677]. Others associate it with the word secāre - to cut, cut off [12, p. 842], [13, 
p. 674], i.e. in its most general form, "sect" can mean "a part of the whole".

The Greek word heresy

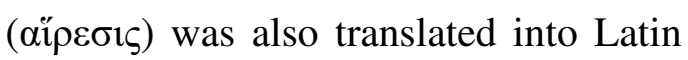
by the term secta and simply meant direction, school, teaching. Later, these concepts were divided: a sect began to mean a community that accepted a doctrine, new or contrary to the one from which it was separated, and heresy - the content of the doctrine itself.

In early antiquity, this word had no negative meaning and was perceived neutrally in the original linguistic context. It acquired a predominantly religious connotation, possibly after Pliny the Younger and Cornelius Tacitus, at the end of the 1st - beginning of the 2 nd centuries, who called the first Christians as the sect [14, p. 194]. And Christians themselves at first called themselves a sect (in the sense of a philosophical school). For example, Tertullian in his "Apologies" repeatedly called Christians "the divine sect", "the Christian sect" and "our sect" [15].

And the same Christians added here a certain negative nuance, which subsequently played a cruel joke with them during the New and Recent History, when the "sect" was fixed as a term that carries an absolutely negative meaning. Lactantius, a Christian apologist at the beginning of the 4th century, used it in the composition of the Seven Books of Divine Establishments as a word for schisms in the Christian church itself: First of all, you need to know that the Savior and the apostles predicted that there would be sects and heresies that would destroy the unity of believers ..." [16].

The Reformation Churches, which the Catholics naturally referred to as sects, also used this word to refer to other believers. For example, Martin Luther often used it in his polemic with opponents: "I warn you about this so seriously, in view of the danger that numerous misconceptions and sects Arians, Eunomians, Macedonians and other heretics - harm the churches with their cunning." Luther included his contemporaries to these sects Anabaptists and other radical movements of the Reformation, which he called "fanatics" [17, p. 28, 34, 52.].

All the subsequent time, up to now, the "sect" in folk speech (and among educated people) is perceived not by its basic meaning, but by its uniquely negative connotation. 
In the twentieth century, sociologists and Protestant theologians attempted to use the word "sect" in its original, neutral sense, i.e. as a breakaway part of some structure or a religious neoplasm that has adopted a different doctrine. This, for example, is the definition of "sect" proposed by E. Trölcz and M. Weber, as a community of believers, distinguished from the church by less stability in time and space, defined by isolation and focused not on the people, country or culture, but on a specific person [18,25], [19, 24]. Or the definition by R. Niebuhr, who represented the sect as an initial religious formation, which could either disintegrate or evolve into the next type of religious association over time denomination (in the typology of Niebuhr) and further into the highest association level - the church.

Some religious scholars have adopted such definitions, but the majority of the population of Russia (figuratively speaking, the main "consumer" of the word "sect") has not even paid attention to the findings of scientists and continues to perceive it in the usual, negative sense. Moreover, in the 90-ies of the twentieth century some "sectarian scholars" added the adjective "totalitarian" to it. Russians know about totalitarianism "first hand" and the use of this word causes them quite specific negative associations with the atheistic ideology and punitive system that existed in the USSR.

Thus, the "sect", reinforced by the word "totalitarian", continues to be distributed through print media, television programs, official documents, moreover, most often in relation to any religious communities (and even centralized organizations with tens of thousands of members ${ }^{2}$ ) that are not traditional.

The experts began to use the term "sect" in the Russian language from the 17th-18th centuries, and this word and its derivatives are in regular use only by the middle of the 19th century. Moreover, in dictionaries it unambiguously takes on a negative meaning, and in language communication it is used in the vast majority to express a negative assessment of a religious experience alien to a person. The reason for this is probably rooted in the subjective perception of the word "sect." We noted above that one of its meanings is the 
"breakaway part" (secāre - to cut, to cut off), i.e. in a religious context, this is juxtaposed as part and whole and is already perceived as a kind of contrast between personal and social, individualism and collectivism. Therefore, according to some scholars, "behind the rejection of "sectarianism" as the right to religious dissent, the preference of the public to the private, collective values to the individual, is rooted which is characteristic of the eastern mentality" [21,22,23].

However, the most important and dangerous, in our opinion, is the fact that the "sect" is characterized by the extreme relativity of the definition criteria. Comparison of this term definitions in different dictionaries shows that, firstly, they often differ greatly among themselves and, secondly, some concepts are given without taking into account historical and geopolitical conditions. For example, in the encyclopedic dictionary "Christianity" it is said: "A sect is an organized society of people who disagree with the dominant church, but who agree with each other religiously" [22, p. 533]. The dominant church in the Russian Empire really existed, but in the Russian Federation the
Constitution does not provide such a status for any religious organization. And if we talk about Catholic or Lutheran countries, then the Orthodox communities, being small in number, can have all the signs of a sect. Therefore, in such a situation, the above definition loses its meaning and misleads the reader.

In addition, under the influence of the media, the propaganda activities of anti-cultists, and the general religious illiteracy of the population the "sectarian" has established itself as an alien, focused on other socio-cultural values in the modern consciousness of the average Russian; a fanatic who is hostile to traditional religions, a hallmark of which is a low cultural level and social isolationism.

Of course, all these signs cannot be taken as the basis for the scientific definition of "sectarianism," since they do not reflect the general laws of these religious movements existence and development. Rather, they are manifested in the personal religiosity of some believers of almost all faiths. Nevertheless, extending the above qualities precisely to "sectarians", the philistine mind seems to convince itself 
of their unreliability and potential danger to society. And if such a person belongs to an indigenous nation, the cultural tradition of which is any particular religion, he becomes not only a religious dissident, but also a "traitor to the nation", etc.

\section{Summary}

Thus, summarizing, it can be stated that there is no clear and adequate definition of the concept "sect" in modern religious science, which, most likely, cannot be worked out due to the lack of objective criteria for it.

The existing definitions ultimately do not meet the criteria of scientific nature - truth, objectivity, and system, for they reflect either confessional views or value judgments.

If we talk about legal definition, then, for the same reasons, any wording will turn out to be erroneous and make the term "sect" a tool for dishonest law enforcement, since, being legislatively fixed, it can be applied to any religious community. And the consequences will be the same as in the case with the amendment to the Federal Law "On Freedom of Conscience and Religious Associations" introduced by the notorious "Spring Law": initially adopted to combat Islamic extremism, it did not allow any ISIS recruiter to be held accountable, however, about 400 administrative cases were instituted (and continue to be instituted) in relation to other religious denominations that have nothing to do with extremism.

The legal definition of this term will ultimately inevitably lead to the fact that they will not be held accountable for a specific offense, but for belonging to a religious association recognized as a "sect." Alas, this is not a hyperbole: history knows similar times, beginning with the first Christians who were punished and even killed for belonging to the "sect", Montanists in the 2nd century, Cathars in the 12th century, Anabaptists in the 16th century, and Pentecostals in the 20th century.

\section{Conclusions}

Unfortunately, it is our human property to concentrate all the negative feelings (not knowledge!) that we get through the media and "kitchen" conversations in one word "sect". It got to the point that one only has to say "sectarian," to form the image of the real enemy, even if everyone knows him as 
an honest, respectable, and law-abiding person and citizen.

I would like to recommend to lawmakers, and especially law enforcers, not to respond to a word whose meaning has not been scientifically defined in the last two thousand years (and probably will not be), but to illegal actions of specific individuals and legal entities, regardless of religious affiliation. And already the state has enough methods of influencing the violators of the law without such very reckless innovations.

\section{Acknowledgements}

The work is performed according to the Russian Government Program of Competitive Growth of Kazan Federal University.

\section{References}

Information about the open tender No. $0173100009618000099 \quad$ [Electronic resource]. - Access mode: http://www.zakupki.gov.ru/epz/order/no tice/ok44/view/commoninfo.html?regNumber $=0173100009618$ $\underline{000099}$ (reference date: 19.12.2018).

The State Duma and the Moscow City Duma think about the concept of "sect"
[Electronic resource]. - Access mode: https://www.aboutdvorkin.ru/news.php?id=93328

(reference date: 23.12.2018).

Moscow City Duma proposed to equate sects with commercial organizations operating under the guise of scientific [Electronic resource]. - Access mode: https://www.mskagency.ru/materials/28 $\underline{04218}$ (reference date: 17.12.2018).

Mizulina proposes to develop a draft law to combat destructive sects [Electronic resource]. - Access mode: https://tass.ru/obschestvo/3791640 (reference date: 17.12.2018).

The composition of the working group to develop the law against the "sects". Who are all these people? [Electronic resource]. - Access mode: https://www.aboutdvorkin.ru/news.php?id=93292 (reference date:18.12.2018).

Leo F. Stelten. Dictionary of Ecclesiastical Latin. Hendrickson Publishers. 1995. 330 p. 
Religious Studies: Encyclopedic

Dictionary - M.: Academic Project, 2006, 1256 p.

The latest dictionary of religious studies / Compiled by O.K. Sadovnikov, G.V. Zgursky; Edited by S. N. Smolensky. Rostov on Don: Phoenix, 2010, 445 p.

Irmsher J., Jone R. Dictionary of Antiquity. Translation from German by V.I. Gorbushin - M.: Progress, 1989, 704 p.

Apulia. Apology, or Speech in defense of oneself against accusations of magic. Metamorphoses. Florida. / Translation by M.A. Kuzmin and S.P. Markish. - M.: Publishing House of the Academy of Sciences of the USSR. 1956, 435 p.

Charlton T. Lewis, Charles Short A Latin Dictionary. Oxford At The Clarendon Press. 1969. 2019 p.

The Oxford England Dictionary. Oxford, 1989. Vol. XIV. 1024 p.

The Catholic Encyclopedia. N. Y., 1912. Vol. XIII. 936 p.
Ranovich A.B. The primary sources on the history of early Christianity. Antique critics of Christianity. M., Politizdat, 1990. 479 p.

15. "Apologetics (Apologeticus) by Qu. Sept. Flor. Tertullian. Part 1. Apologetic works of Tertullian. / Translation by N. Shcheglov. - Kiev: The printingoffice of JSC "Peter Barsky, in Kiev." 1910. - pp. 81-204.

Lucius Caecilius Firmianus Lactantius. Liber Quartus. De uerasapientia et religione. CAPUT XXX. De Haeresibus et Superstitionibusvitandis, et quae sit sola et vera Ecclesia Catholica. //De divinis Institutionibus libri VII [Electronic resource]. - Access mode: http://remacle.org/bloodwolf/eglise/lact ance/instit4.htm (reference date: 03.01.2019).

Luther M. Lectures on the Epistle to the Galatians. - M.: Lutheran Heritage Foundation, 1997. 705 p.

Troelch E. Social doctrine of Christian churches and groups // Religion and Society. Reader on the sociology of 
religion / Comp. by Garaja V.I., Rutkevich E.D. - M., 1996. 775 p.

Weber Max Selected Works / Ed. by Doctor in Philosophy Yu. Davydov. M., 1990. - 808 p.

The Russian United Union of Christians of the Evangelical Faith (Pentecostals) [Electronic resource].

URL:https://www.cef.ru/ (reference date: 04.01.2019).

Prilutsky A.M., Pogasy A.K. "The concept of "sect": basic meanings and the legitimacy of use // Religious studies. - 2006. - No. 1. - pp. 164-170.

“Christianity": Encyclopedic Dictionary. - M: "GSE", 1995. - V 2. 2317 p.

Sadeghpour, F., Far, M. G., Khah, A. R., \& Akbardokht Amiri, M. A. (2017). Marketing Strategic Planning and Choosing the Right Strategy using AHP Technique (Case Study: Ghavamin Bank Mazandaran). Dutch Journal of Finance and Management, 1(2), 45. https://doi.org/10.29333/djfm/5821
Kvet, M., \& Matiasko, K. (2018). Temporal Data Performance Optimization using Preprocessing Layer. Journal of Information Systems Engineering \& Management, 3(2), 13.

Hasibuan, A. M., Saragih, S., \& Amry, Z. (2019). Development of Learning Materials Based on Realistic Mathematics Education to Improve Problem Solving Ability and Student Learning Independence. International Electronic Journal of Mathematics Education, $\quad 14(1), \quad 243-252$. https://doi.org/10.29333/iejme/4000

Abayeva, G. (2018). Modern teacher role for increasing the students' competence in pedagogical specialty. Opción, 34(85-2), 415-440

${ }^{1}$ See, for example: Decision of the Kalinin District Court of Chelyabinsk dated on October 2, 2000 No. 2-263/2000; The decision of the Moscow Arbitration Court on October 20, 2006 (case No. A-40-156939 / 06146-149); the Decision of the Federal Antimonopoly Service of the Moscow District dated on January 31, 2007, February 7, 2007 No. KA-A40 / 13939- 
06 on the case No. A40-15693 / 06-146-

149; The ruling of the Moscow City

Court on March 12, 2012 for the case No.

$33-7562$.

${ }^{2}$ For example, the head of the Center for Religious Studies named after the holy martyr Irenaeus of Lyons, Alexander Dvorkin, the same "main sectologist," consider Pentecostals as sects: "The largest and most influential sects in Russia: the Pentecostal (Russian United Union of Christians of the Gospel Faith)". The members of ROSHVE are 29 associations uniting about 2000 communities [20]. 